\title{
Chemical Composition and Nutraceutical Potential of Indian Borage (Plectranthus amboinicus) Stem Extract
}

\author{
Praveena Bhatt, ${ }^{1}$ Gilbert Stanley Joseph, ${ }^{2}$ Pradeep Singh Negi, \\ and Mandyam Chakravarthy Varadaraj ${ }^{4}$ \\ ${ }^{1}$ Fermentation Technology and Bioengineering, CSIR-Central Food Technological Research Institute, Mysore 570020, India \\ ${ }^{2}$ Human Resource Development, CSIR-Central Food Technological Research Institute, Mysore 570020, India \\ ${ }^{3}$ Fruit and Vegetable Technology, CSIR-Central Food Technological Research Institute, Mysore 570020, India \\ ${ }^{4}$ Food Microbiology, CSIR-Central Food Technological Research Institute, Mysore 570020, India \\ Correspondence should be addressed to Pradeep Singh Negi; psnegi@cftri.res.in
}

Received 21 May 2013; Accepted 16 July 2013

Academic Editor: Mehmet Emin Duru

Copyright (c) 2013 Praveena Bhatt et al. This is an open access article distributed under the Creative Commons Attribution License, which permits unrestricted use, distribution, and reproduction in any medium, provided the original work is properly cited.

\begin{abstract}
The stem of Indian borage (Plectranthus amboinicus) was found to be an antioxidant rich fraction as evaluated by in vitro models such as DPPH free radical scavenging, reducing power assay, superoxide anion radical scavenging, and total antioxidant capacity. The extract also exhibited antiplatelet aggregation ability, antibacterial activity, and antiproliferative effect against cancer cell lines: Caco-2, HCT-15, and MCF-7. Phytochemical evaluation of the extract revealed the occurrence of total phenolics (49.91 mg GAE/g extract), total flavonoids ( $26.6 \mathrm{mg} \mathrm{RE} / \mathrm{g}$ extract), and condensed tannins ( $0.7 \mathrm{mg}$ TAE/g extract). Among the major phenolics, rosmarinic acid $(6.160 \mathrm{mg} / \mathrm{g}$ extract) was predominant, followed by caffeic acid $(0.770 \mathrm{mg} / \mathrm{g}$ extract), rutin $(0.324 \mathrm{mg} / \mathrm{g}$ extract), gallic acid $(0.260 \mathrm{mg} / \mathrm{g}$ extract), quercetin $(0.15 \mathrm{mg} / \mathrm{g}$ extract), and $p$-coumaric acid $(0.104 \mathrm{mg} / \mathrm{g}$ extract). The appreciable biological activity and presence of biomolecules in the methanolic extract of stem indicate its potential application as functional food ingredients and nutraceuticals.
\end{abstract}

\section{Introduction}

Plectranthus amboinicus (Lour) Spreng also called as Indian borage has been in use in the Indian system of medicine. It belongs to the family Lamiaceae and is also known as country borage in English [1]. A decoction of the leaves is used for several medicinal purposes, especially respiratory diseases like congestion, bronchitis, sour throat, and digestive diseases like dysentery, diarrhoea, colitis, and so forth. Many pharmacological properties such as urolithiasis, antiepileptic, antitumorogenic, antimutagenic, radioprotective, neuropharmacological, and antimicrobial have been reported for the leaves of $P$. amboinicus [2].

The leaves exhibit significant antioxidant potency, reducing power, superoxide anion radical scavenging ability, nitric oxide radical scavenging, and ferrous ion chelating ability [3]. They contain essential oils, flavonoids, and terpenes which possess inhibitory effect against Gram-positive and
Gram-negative bacteria [4, 5]. Antimutagenic, antitumorogenic, and antigenotoxic effects of Indian borage leaves have also been documented [6]. Although, there is plethora of information on $P$. amboinicus leaves, to our knowledge, no information is available about its stem. In this background, the present investigation was carried out to determine phytochemical composition of $P$. amboinicus stem and to evaluate its selected functional attributes using different in vitro models. The study included antioxidant, antiplatelet, antibacterial, and anticancer properties of stem that could have the potential as nutraceuticals and functional food ingredients.

\section{Materials and Methods}

2.1. Plant Material and Extraction. The stem of P. amboinicus was collected from the plants grown in the campus of CSIRCentral Food Technological Research Institute, Mysore, 
India. The plant material was identified by Mr. A. S. Chauhan, Principal Scientist, Fruit and Vegetable Technology Department, CSIR-CFTRI, Mysore, and a specimen voucher was deposited in the Fruit and Vegetable Technology Departmental Herbarium (FVT DH number. LGMGHCC-PA-8/2011). Stems of $P$. amboinicus in requisite quantities were washed and cut into $\sim 2 \mathrm{~cm}$ length pieces, dried at $55^{\circ} \mathrm{C}$ in a hot air oven (TC-90, Industrial and Laboratory Tools Instrument Corporation, Chennai, India), and ground in a mixer grinder. The powder so obtained was soaked in methanol $(1: 3 \mathrm{w} / \mathrm{v})$ and stirred for $24 \mathrm{~h}$ at $30^{\circ} \mathrm{C}$ on a magnetic stirrer unit. The supernatant was filtered with Whatman filter paper number 41 , and the residue was reextracted with methanol three times using the above procedure. The extracts obtained were pooled, concentrated in a Flash Evaporator (Rotavapor-R, Büchi, Switzerland), and dried under vacuum (25 $\mathrm{mmHg})$ at $40^{\circ} \mathrm{C}$ in a vacuum oven (HE-032, Industrial and Laboratory Tools Instrument Corporation, Chennai, India).

\subsection{Phytochemical Screening}

2.2.1. Estimation of Total Phenolics. The concentration of phenolics in the extract was determined by the method of Singleton and Rossi [7]. Aliquots of the samples in methanol were mixed with $1.0 \mathrm{~mL}$ of 10 -fold diluted Folin-Ciocalteu reagent and $1 \mathrm{~mL}$ of saturated sodium carbonate solution. After allowing it to stand for $30 \mathrm{~min}$ at $30 \pm 2^{\circ} \mathrm{C}$, the absorbance was measured at $765 \mathrm{~nm}$ in a UV-visible spectrophotometer (UV-1601, Shimadzu, Kyoto, Japan). Total phenolics were calculated against the standard gallic acid curve, and results were expressed as mg gallic acid equivalents per gram of extract (GAE/g extract).

2.2.2. Estimation of Total Flavonoids. The method described by El Far and Taie [8] was used for the determination of total flavonoid content in the extract. Aliquots of $1.5 \mathrm{~mL}$ of sample were added to an equal volume of $2 \%$ alcoholic aluminium chloride solution. The mixture was vigorously shaken, and absorbance was read spectrophotometrically at $420 \mathrm{~nm}$ after $30 \mathrm{~min}$ incubation at ambient temperature in a UV-Vis spectrophotometer. Rutin was used as the standard, and flavonoid content was expressed as $\mathrm{mg}$ rutin equivalent per gram of extract (RE/g extract).

2.2.3. Estimation of Condensed Tannins. Proanthocyanidin content was determined using the procedure of Sun et al. [9]. The extract in methanol $(0.5 \mathrm{mg}$ in $0.5 \mathrm{~mL})$ was mixed with $3 \mathrm{~mL}$ of $4 \%$ vanillin-methanol solution and $1.5 \mathrm{~mL}$ of $\mathrm{HCl}$, and the mixture was allowed to stand for $15 \mathrm{~min}$, after which the absorbance was measured at $500 \mathrm{~nm}$. Tannic acid was used as the standard, and total proanthocyanidins were expressed as mg tannic acid equivalents per gram of extract (TAE/g extract).

2.2.4. High Pressure Liquid Chromatography (HPLC) Profile. HPLC was performed in Shimadzu HPLC (LC 10A, SPDMOAVP, Kyoto, Japan) equipped with a quaternary pump and a diode array detector. The mobile phase involved a gradient of water:acetic acid $(100: 1)$ as solvent $A$ and methanol : acetonitrile : acetic acid $(95: 5: 1)$ as solvent $B$ at a constant flow rate of $1.0 \mathrm{~mL} / \mathrm{min}$. The gradient comprised of an initial isocratic period of $2 \mathrm{~min}$ with $5 \%$ solvent $\mathrm{B}$, followed by a linear increase to $25 \%$ with B over 10 min with further stepwise linear increase to $40 \%$ B in $20 \mathrm{~min}, 50 \%$ B in $30 \mathrm{~min}$, and $100 \% \mathrm{~B}$ in $40 \mathrm{~min}$, which was maintained for $5 \mathrm{~min}$ and returned to initial conditions in next $10 \mathrm{~min}$. Samples were dissolved in methanol, and $20 \mu \mathrm{L}$ sample was injected for chromatographic separation. The compounds were identified by comparing their retention times with those of standards at $325 \mathrm{~nm}$ with the exception of gallic acid which was observed at $280 \mathrm{~nm}$. The quantity of the various compounds present was determined from the standard curve using the standards for individual phenolic compounds obtained from SigmaAldrich, Bengaluru, India.

\subsection{Bioactivity Evaluation}

\subsubsection{Antioxidant Activity}

(1) DPPH Free Radical Scavenging Assay. The free radical scavenging activity of the extract was measured by 1,1-diphenyl2-picrylhydrazyl (DPPH) in vitro assay [10]. Aliquots of the sample $(1000 \mu \mathrm{g} / \mathrm{mL})$ in methanol were adjusted to a final volume of $2.5 \mathrm{~mL}$ and mixed with $5 \mathrm{~mL}$ of $0.1 \mathrm{mM} \mathrm{DPPH}$ solution. The change in the absorbance of the samples was measured after $20 \mathrm{~min}$ incubation in dark at $517 \mathrm{~nm}$ in a UVVis spectrophotometer. The percent radical scavenging activity of the extract at different concentrations was determined and compared with that of butylated hydroxy anisole (BHA), which was used as the standard, whereas DPPH solution without extract/standard was used as control. The DPPH free radical scavenging activity was given as

$$
\% \text { radical scavenging activity }=100 \times \frac{\left(A_{0}-A_{s}\right)}{A_{0}},
$$

where $A_{0}$ is absorbance of control and $A_{s}$ is absorbance of sample.

(2) Reducing Power Assay. The reducing power of the methanolic extract of stem was determined by the method of Oyaizu [11]. Extracts dissolved in water were mixed with $5 \mathrm{~mL}$ sodium phosphate buffer $(0.2 \mathrm{M}, \mathrm{pH} 6.6)$ to a final concentration of $25,50,75,100$, and $125 \mathrm{ppm}$, and $2.5 \mathrm{~mL}$ of $1 \%$ potassium ferricyanide was added to individual concentrations. The mixture was incubated for $20 \mathrm{~min}$ at $50^{\circ} \mathrm{C}$. At the end of the incubation period, $2.5 \mathrm{~mL}$ of $10 \%$ trichloroacetic acid was added to the mixture and centrifuged (Rota 4R-V/FM, Plasto Crafts Industries (P) Ltd., India) at $5000 \mathrm{rpm}$ for $10 \mathrm{~min}$ at $27^{\circ} \mathrm{C}$. The upper layer of the solution $(2.5 \mathrm{~mL}$ ) was mixed with $2.5 \mathrm{~mL}$ of Milli-Q (Advantage A10, Millipore, Molsheim, France) water and $0.5 \mathrm{~mL}$ of $0.1 \% \mathrm{FeCl}_{3}$. The reducing power was expressed in terms of absorbance of this solution at $700 \mathrm{~nm}$ in a UV-Vis spectrophotometer. Ascorbic acid was used as a positive control.

(3) Superoxide Anion Radical Scavenging Activity. The superoxide anion radical scavenging activity was measured as 
described by Robak and Gryglewski [12] using phenazine methosulphate (PMS) system. The superoxide anion radicals were generated in $3.0 \mathrm{~mL}$ system containing $0.5 \mathrm{~mL}$ nitroblue tetrazolium (NBT, $0.3 \mathrm{mM}), 0.5 \mathrm{~mL} \mathrm{NADH}(0.936 \mathrm{mM})$, $1.0 \mathrm{~mL}$ extract of varying concentrations, and $1.0 \mathrm{~mL}$ Tris- $\mathrm{HCl}$ buffer $(16 \mathrm{mM}, \mathrm{pH} 8.0)$. A mixture without the extract served as the control. To this $0.5 \mathrm{~mL}$ of phenazine methosulphate (PMS) solution $(0.12 \mathrm{mM}$ ) was added and incubated for $5 \mathrm{~min}$ at $25^{\circ} \mathrm{C}$, and then the absorbance was measured at $560 \mathrm{~nm}$ in a UV-Vis spectrophotometer against Milli-Q water as blank. Gallic acid was used as a positive control, and \% scavenging activity was determined using (1) described previously.

(4) Total Antioxidant Capacity. The total antioxidant capacity of the extracts was evaluated by phosphomolybdenum method [13]. An aliquot of $0.3 \mathrm{~mL}$ of extract $(1000 \mu \mathrm{g} / \mathrm{mL})$ was combined with a mixture of $3 \mathrm{~mL}$ of reagent solution (0.6 M sulphuric acid, $28 \mathrm{mM}$ sodium phosphate, and $4 \mathrm{mM}$ ammonium molybdate) and incubated for $90 \mathrm{~min}$ at $95^{\circ} \mathrm{C}$. After the samples were cooled to ambient temperature, the absorbance of the solution was measured at $695 \mathrm{~nm}$ in a UVVis spectrophotometer against solvent blank. Ascorbic acid was used as a positive control, and the results were reported as $\mu \mathrm{M}$ ascorbic acid equivalents/g of extract.

2.3.2. Antiplatelet Aggregation Activity. Platelet aggregation was performed on a Dual Channel Optical Aggregometer (Model 490-2D, Chronolog, Havertown, PA, USA) equipped with AGGRO/LINK Software, following the manufacturer's manual. Blood samples drawn from healthy human volunteers were anticoagulated with $3.2 \%$ sodium citrate (whole blood and anticoagulant ratio 9:1). Platelet-rich plasma (PRP) was obtained by centrifugation of the citrated blood at $800 \mathrm{rpm}$ for $10 \mathrm{~min}$ at $27^{\circ} \mathrm{C}$. Platelet-poor plasma (PPP) was obtained by further centrifugation of the residual blood at $4000 \mathrm{rpm}$ for $15 \mathrm{~min}$ at $27^{\circ} \mathrm{C}$. PRP $(0.5 \mathrm{~mL})$ adjusted to a final count of $2 \times 10^{5}$ platelets $/ \mathrm{mL}$ using PPP was continuously stirred at $1200 \mathrm{rpm}$ at $37^{\circ} \mathrm{C}$, and platelet aggregation was determined turbidimetrically by adding an agonist (Adenosine Diphosphate, $20 \mu \mathrm{M}$ final concentration) to the PRP. For testing the antiplatelet activity, varying concentrations $(50-250 \mu \mathrm{g} / \mathrm{mL}$ PRP) of the extract were added prior to the addition of agonist. A control without the extract was also included (PRP control). The antiplatelet activity was expressed as percentage inhibition of platelet aggregation and was calculated as follows:

$$
\text { antiplatelet activity }(\%)=\frac{\left[A_{C}-A_{T}\right]}{A_{C}} \times 100,
$$

where $A_{C}(\%)=$ aggregation of PRP control and $A_{T}(\%)=$ aggregation of PRP treated with extract.

2.3.3. Antibacterial Activity. Bacterial strains, namely, Bacillus cereus F 4810 (Public Health Laboratory, London, UK), Staphylococcus aureus FRI 722 (Public Health Laboratory, The Netherlands), Escherichia coli MTCC 108 (Microbial Type Culture Collection, Institute of Microbial Technology, Chandigarh, India), and Yersinia enterocolitica MTCC 859
(Microbial Type Culture Collection, Institute of Microbial Technology, Chandigarh, India) were grown overnight in brain heart infusion (BHI) broth at $37^{\circ} \mathrm{C}$. The antibacterial activity was determined by the standard broth dilution method [14]. The minimum inhibitory concentration (MIC) was defined as the lowest concentration of extract that visually inhibited complete growth of bacteria, while the minimum bactericidal concentration (MBC) was defined as the lowest concentration that kills $100 \%$ of the initial bacterial population on agar plate. Nisin was used as a positive control for comparison.

2.3.4. Cytotoxic Activity against Cancer Cell Lines. Human cancer cells, Caco-2 (human adenocarcinoma), HCT-15 (human colon adenocarcinoma), and MCF-7 (human mammary gland; breast adenocarcinoma) were purchased from National Centre for Cell Science, Pune, India. The cells were cultured in DMEM supplemented with 10 or $20 \%$ foetal bovine serum (Sigma-Aldrich, India), sodium pyruvate (Sigma-Aldrich, India), and penstrep (Invitrogen, India) and maintained at $37^{\circ} \mathrm{C}$ with $5 \% \mathrm{CO}_{2}$ in a humidified atmosphere (Galaxy 170S, Newbrunswick, UK). The cytotoxic activity of stem extract on various cell lines was measured by MTT assay as described by Yesil-Celiktas et al. [15]. Cytotoxicity was determined according to the percent cell viability using MTT assay, and half maximal inhibitory concentration $\left(\mathrm{IC}_{50}\right)$ was also calculated from the growth inhibition curve.

2.4. Statistical Analysis. The results obtained in the experiments were expressed as mean $\pm \mathrm{SD}(n=3)$. The data were analyzed by one-way ANOVA. Duncan's multiple range test (DMRT) was used to make the comparisons between the means.

\section{Results and Discussion}

3.1. Antioxidant Activity. The high antioxidant potential in the stem of $P$. amboinicus was evident by the values obtained in selected in vitro assays. The results of the DPPH free radical scavenging activity of the stem extract of $P$. amboinicus at different concentrations are given in Figure 1. Methanolic extract of the stem showed significantly higher $(P \leq 0.05)$ DPPH free radical scavenging activity at $180 \mathrm{ppm}(\sim 96 \%)$ than at other concentrations. The synthetic antioxidant (BHA) showed a similar activity at $20 \mathrm{ppm}$. Although, higher concentration of the extract is required for an equivalent activity, use of natural antioxidants will ameliorate several adverse health effects reported for synthetic antioxidants [16]. The DPPH free radical scavenging activity of the methanolic extract of Indian borage stem was found to be higher (96\% at $200 \mathrm{ppm}$ ) than the activity reported for the aqueous extract of the leaves $(72.7 \%$ at $300 \mathrm{ppm})$ by Kumaran and Karunakaran [3]. The observed higher activity in the stem extract may be due to the difference in tissue (leaf and stem) and/or the solvent system used for the extraction or variable bioactive molecules present in them. Reports are available in the literature with similar observations, wherein the radical scavenging activity is more pronounced in the stem of a plant 


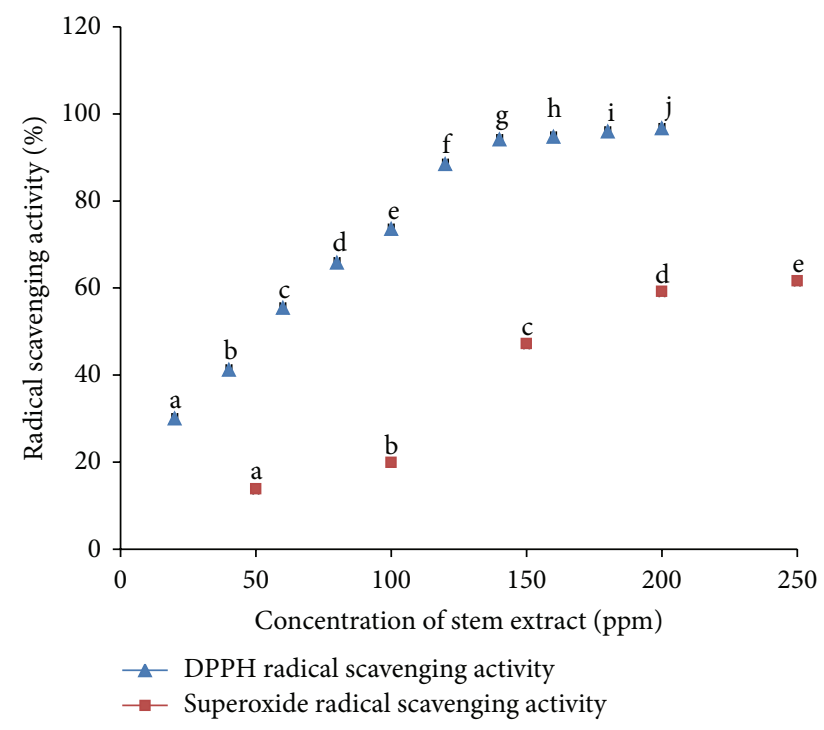

FIGURE 1: DPPH free radical and superoxide anion radical scavenging activities of stem of Plectranthus amboinicus at different concentrations. Values followed by different letters are significantly different $(P<0.05)$ from each other in each assay.

TABle 1: Reducing potential of methanolic extract of stem of Plectranthus amboinicus.

\begin{tabular}{lcc}
\hline Concentration $(\mathrm{ppm})$ & Methanolic extract & Ascorbic acid $^{*}$ \\
\hline 25 & $0.085 \pm 0.003^{\mathrm{a}}$ & $0.894 \pm 0.001^{\mathrm{a}}$ \\
50 & $0.161 \pm 0.008^{\mathrm{b}}$ & $1.77 \pm 0.17^{\mathrm{b}}$ \\
75 & $0.227 \pm 0.004^{\mathrm{c}}$ & ND \\
100 & $0.293 \pm 0.006^{\mathrm{d}}$ & ND \\
125 & $0.347 \pm 0.021^{\mathrm{e}}$ & ND \\
\hline
\end{tabular}

${ }^{*}$ Ascorbic acid was used as a positive control.

ND: not detectable; values are not readable in spectrophotometer (>3.7 OD). Values followed by different letters in a column are significantly different $(P \leq 0.05)$ from each other.

as against to that in leaves such as in Kigelia sp. [17] and Glycosmis pentaphylla [18].

The reducing power assay gives an indication of the antioxidant potential of a plant material. Earlier researchers have found a direct correlation between antioxidant activity and reducing power ability of certain plant extracts [19, 20]. Compounds with reducing power ability can reduce the oxidized intermediates of lipid peroxidation processes and thereby act as primary and secondary antioxidants [21]. Results of the reducing power assay carried out with the methanolic extract of stem showed that the reducing potential increased significantly $(P \leq 0.05)$ with increasing concentrations (Table 1), indicating that the antioxidant properties of the extract were concentration dependant. However, the reducing activity of the extract was much lower than ascorbic acid which was used as a positive control. Appreciable reducing potential in hydroalcoholic extract of Indian borage leaves has also been reported [3]. Similar to our study in stem, the reducing power of the leaf extract increased with increase in concentration.
The antioxidant potential of the stem extract was also evaluated using the superoxide anion radical scavenging model. The superoxide anion radical scavenging activity exhibited by stem extract was evaluated using the PMS/NADH-NBT system, in which NBT is reduced by the superoxide anion generated from dissolved oxygen by the $\mathrm{PMS} / \mathrm{NADH}$ coupling reaction. The superoxide anion radical scavenging activity of the methanol extract of stem was dose dependant and increased significantly $(P \leq 0.05)$ with increase in concentration (Figure 1). However, at higher concentrations, a saturation effect was observed. In our study, an appreciable scavenging activity was observed (61\%) at $250 \mathrm{ppm}$ indicating that the extract contains antioxidants that can scavenge superoxide anions. Gallic acid used as a positive control showed an equivalent activity at a much lower concentration $(\sim 70 \%$ at $50 \mathrm{ppm})$. The superoxide anion radical scavenging activity of the stem extract of $P$. amboinicus, reported in our study, was not comparable to the higher scavenging activity reported for its leaves using riboflavin-NBT light system $(66.5 \%$ at $100 \mathrm{ppm})$ by Kumaran and Karunakaran [3] but was higher than alcoholic leaf extracts of Hygrophila schulli [22] using the PMS/NADHNBT system (38\% at $1000 \mathrm{ppm}$ concentration) indicating that RSA can vary depending on tissue type as well as plant species.

The total antioxidant capacity of the extract was evaluated using the phosphomolybdenum method. The stem extract showed a total antioxidant capacity of $634.95 \mu \mathrm{M} \mathrm{AAE} / \mathrm{g}$ of extract. In our previous study on borage leaves [5], the total antioxidant capacity of methanolic extract of leaves was found to be $782.56 \mu \mathrm{M} \mathrm{AAE} / \mathrm{g}$ of extract. The total antioxidant capacity of plant extract varies, depending on the type and content of phenolics. Higher total antioxidant capacity (245-376 mg ascorbic acid equivalent/g of extract) has been reported in different species of Phyllanthus [23] having higher amounts of phenolics and flavonoids.

3.2. Antiplatelet Aggregation Activity. The stem extract was tested for its antiplatelet aggregation activity at different concentrations (50-250 $\mu \mathrm{g} / \mathrm{mL}$ PRP) using ADP as an agonist. Results show that the antiplatelet aggregation ability of the extract was dose dependant (Figure 2). Significantly higher $(P \leq 0.05)$ activity was observed at $250 \mu \mathrm{g} / \mathrm{mL}$ of PRP. Although 100 and $200 \mu \mathrm{g} / \mathrm{mL}$ PRP gave statistically similar activity $(P \leq 0.05)$, it was significantly higher $(P \leq 0.05)$ than $50 \mu \mathrm{g} / \mathrm{mL}$. These results are comparable to studies reporting 60-80\% platelet inhibition using other plant extracts [24]. It is well known that platelets play a crucial role not only in hemostasis but also in the development of cardiovascular disorders. Platelet activity can influence the progression of disease as well as the stability of atherosclerotic plaques [25]. Thus, natural antithrombotic agents that exhibit antiplatelet aggregation and influence platelet function are of potential interest in the prevention of cardiovascular diseases.

3.3. Antibacterial Activity. The antibacterial activity of the methanolic extract of stem against various bacteria is shown in Table 2. The MIC for the stem extract against the selected 


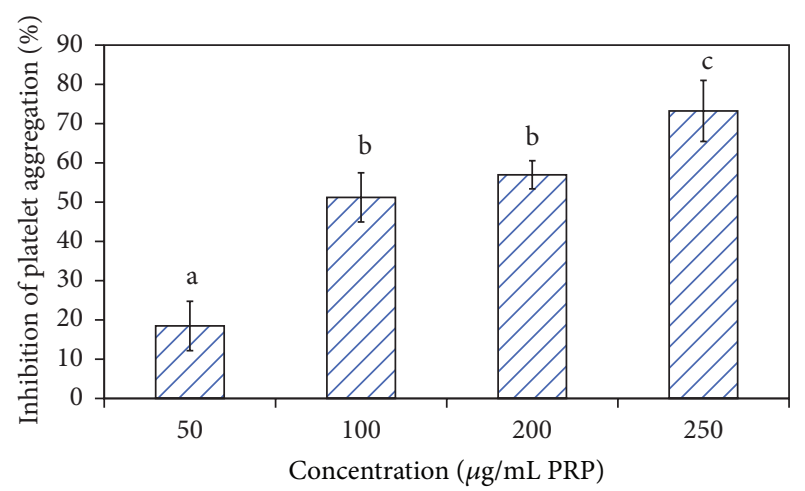

FIGURE 2: Antiplatelet aggregation activity of methanolic extract of stem of Plectranthus amboinicus at different concentrations. Values followed by different letters are significantly different $(P<0.05)$ from each other.

TABLE 2: Minimum inhibitory concentration (MIC) and minimum bactericidal concentration (MBC) of the methanolic extract of stem against selected foodborne pathogens.

\begin{tabular}{lcccc}
\hline Pathogen & \multicolumn{2}{c}{ MIC $(\mathrm{ppm})^{*}$} & \multicolumn{2}{c}{ MBC $(\mathrm{ppm})^{* *}$} \\
$\begin{array}{c}\text { Methanolic } \\
\text { extract }\end{array}$ & Nisin*** & $\begin{array}{c}\text { Methanolic } \\
\text { extract }\end{array}$ & Nisin \\
\hline E. coli & 1750 & 80 & 2000 & 100 \\
S. aureus & 1500 & 90 & 2000 & 100 \\
B. cereus & 3000 & 100 & 5000 & 100 \\
Y. enterocolitica & 750 & 70 & 1000 & 80 \\
\hline
\end{tabular}

${ }^{*}$ Concentration (3 replications) where no visible growth was observed in broth.

${ }^{* *}$ Concentration ( 3 replications) where no growth was observed on agar plate.

${ }_{* * *}^{*}$ Nisin was used as a positive control.

foodborne pathogens was found to be in the range of 750$3000 \mathrm{ppm}$, while the MBC was found to vary from 1000$5000 \mathrm{ppm}$, depending on the test bacterium. A higher MIC (2500-5000 ppm) of methanol extract of leaves against the same bacteria was observed in our earlier study [5]. Also, the methanolic extract of stem had the highest antibacterial activity against $Y$. enterocolitica (MIC of $750 \mathrm{ppm}$ ), while our earlier study found the methanolic extract of leaves to be less effective against the same organism (MIC of $3750 \mathrm{ppm}$ ). A similar pattern was observed for $\mathrm{MBC}$ values also. The stem extract showed weak antibacterial activity as compared to Nisin (MIC range of 70-100 ppm and MBC range of $80-100 \mathrm{ppm}$ ), which was used as a positive control in the present study. Various plant extracts are known to possess antimicrobial activity, which varies with the extract and the bacterial culture in question [26].

3.4. Cytotoxic Activity against Cancer Cell Lines. The stem extract showed variable cytotoxic effect against the cell lines analysed in the study (Figure 3). The stem extract was found to have the strongest cytotoxic effect against HCT-15 with $73.58 \%$ cell viability inhibition at $1000 \mathrm{ppm}$, followed by MCF-7 (55.17\%) at the same concentration, and these were

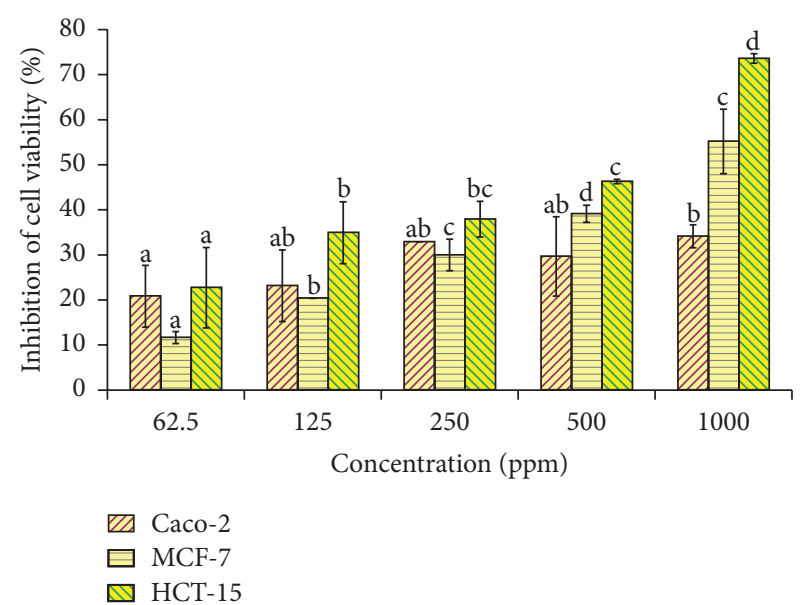

FIgURe 3: Cytotoxic activity of methanolic extract of stem against Caco-2, MCF-7, and HCT-15 cancer cell lines at different concentrations. Values followed by different letters for each cell line are significantly different $(P<0.05)$ from each other.

significantly $(P \leq 0.05)$ higher than inhibitions of cell viability at other concentrations used. Its cytotoxic effect was least for Caco-2 cell line with a cell inhibition of 34.13\% at $1000 \mathrm{ppm}$. The $\mathrm{IC}_{50}$ values against the cell lines were 650, 995, and $2090 \mathrm{ppm}$ for HCT-15, MCF-7, and Caco-2, respectively. The cytotoxic activity of methanolic extract of stem in our study was found to be dose dependant, similar to the antitumorogenic effect of the hydroalcoholic extract of the leaves of $P$. amboinicus $[6,27]$. Our study using the methanolic extract of the stem indicates that stems appear to have an antiproliferative effect on cancer cell lines and hence can exhibit anticancer activity.

3.5. Phytochemical Screening. In our investigation, phytochemical screening of the extract of stem revealed that it contained good amounts of total phenolics (49.91 mg GAE/g of extract), flavonoids ( $26.6 \mathrm{mg} \mathrm{RE} / \mathrm{g}$ of extract), and proanthocyanidins $(0.7 \mathrm{mg}$ TAE/g of extract). Plant polyphenols (flavonoids, flavonols, proanthocyanidins, phenolic acids, etc.) have been associated with antioxidant, antibacterial, anticancerous, and antiplatelet activities. Studies for the identification of bioactive molecules in the extract by HPLC showed the presence of some known antioxidant molecules, namely, rosmarinic acid $(6.160 \mathrm{mg})$, caffeic acid $(0.770 \mathrm{mg})$, rutin $(0.324 \mathrm{mg})$, gallic acid $(0.260 \mathrm{mg})$, quercetin $(0.15 \mathrm{mg})$, and $p$-coumaric acid $(0.104 \mathrm{mg})$ per gram of dried extract (Figure 4). For comparison, we also prepared a methanol extract of the leaves which showed the presence of rosmarinic $(0.0573 \mathrm{mg} / \mathrm{g})$, caffeic $(0.056 \mathrm{mg} / \mathrm{g}), p$-coumaric acid $(0.0746 \mathrm{mg} / \mathrm{g})$, and quercetin $(3.99 \mathrm{mg} / \mathrm{g})$ per gram of dried extract. Rutin and gallic acid were absent in the methanol extract of borage leaves.

Although, no report exists about phytochemical profile in stem, a previous study carried out on leaves by Kumaran and Karunakaran [28] reported rosmarinic acid $(9.4 \mathrm{mg})$, caffeic acid $(0.8 \mathrm{mg})$, and chlorogenic acid $(0.9 \mathrm{mg})$ per gram 

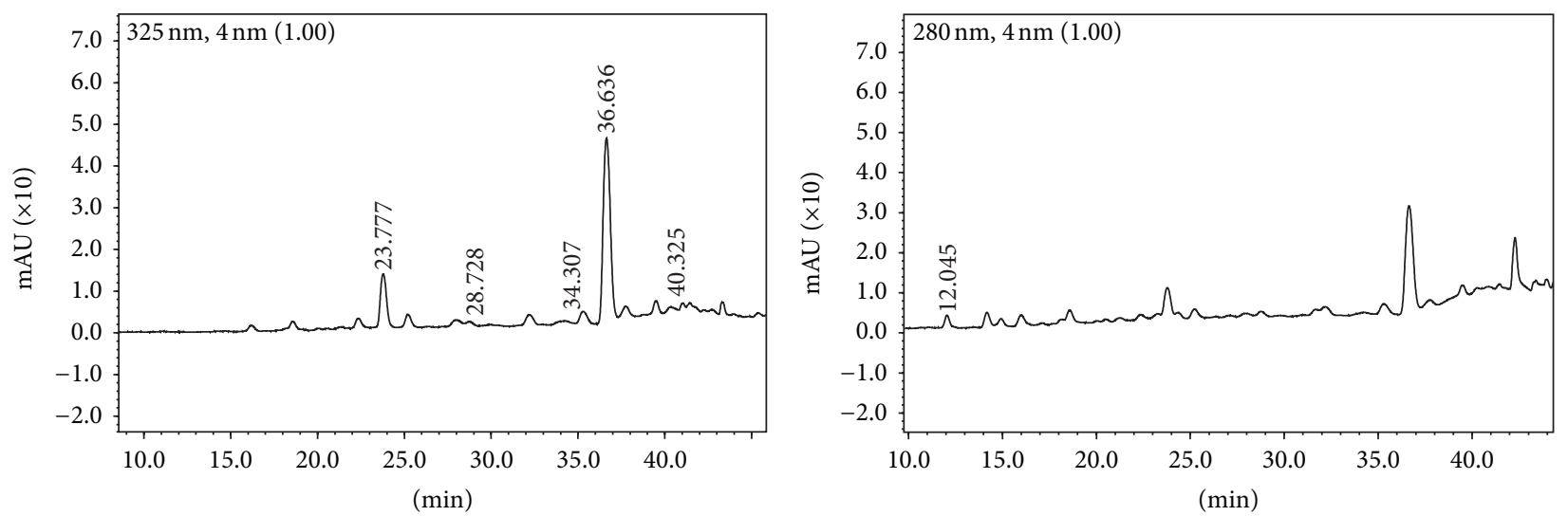

FIGURE 4: HPLC chromatogram of the crude methanolic stem extract of Plectranthus amboinicus. Antioxidants present and their corresponding retention times ( $\mathrm{min})$; gallic acid $-12.04(280 \mathrm{~nm})$; caffeic acid-23.77 (325 nm); p-coumaric acid-28.72 (325 nm); rutin-34.30 $(325 \mathrm{~nm})$; rosmarinic acid-36.63 $(325 \mathrm{~nm})$; and quercetin-40.32 $(325 \mathrm{~nm})$.

of dried extract to be the major antioxidant molecules in $P$. amboinicus. Rosmarinic acid followed by caffeic acid are the major compounds in both stem (present investigation) and aqueous extracts of leaves of Indian borage [28]. Although, the quantity of these compounds in our study is relatively less in comparison to that reported in the leaves by these authors, the differences may be attributed to tissue, varietal, and climatic variations. We were also able to identify other bioactive molecules like gallic acid, quercetin, rutin, and $p$ coumaric acid which were present in appreciable amounts in the crude extract of stem.

Rosmarinic acid, an ester of caffeic acid, whose other biological activities are well reported, has also shown antiproliferative effect on murine mesangial cells via a mechanism involving inhibition of platelet-derived growth factor (PDGF) and tumor necrosis factor (TNF) [29]. Gallic acid has been shown to actively inhibit the proliferation of cancer cells [30], and quercetin and its analogues are reported to be anticancerous [31]. Quercetin and quercetin glucosides like rutin have strong antiplatelet aggregation, anticancer and antibacterial activities [31-33]. Probably, the biological activities in the stem extract observed in our study were due to the presence of these bioactive compounds. The presence of these absorbable biomolecules and appreciable biological activities in the extract of stem indicates their potential application as functional food ingredients and nutraceuticals.

\section{Conclusion}

The methanolic extract of the stem of P. amboinicus was found to be an antioxidant rich fraction and showed antiplatelet aggregation ability, antibacterial activity against foodborne bacterial pathogens and antiproliferative effect on cancer cells. The stem extract showed appreciable quantities of antioxidant molecules like rosmarinic acid, caffeic acid, coumaric acid, gallic acid, quercetin, and rutin, and probably, the biological activities observed in present study were due to the presence of these bioactive compounds. The presence of biomolecules and appreciable biological activities in the methanolic extract of Indian borage stem indicates its potential application as functional food ingredients and nutraceuticals.

\section{Acknowledgments}

The authors thank the Director of CSIR-CFTRI, Mysore, India for providing infrastructural facilities. Also thanks are due to Mr. A. S. Chauhan, for identification of plant, Ms. N. Poornima, for platelet count, and Mr. Mukund, for help in HPLC.

\section{References}

[1] K. R. Kirtikar and B. D. Basu, Indian Medicinal Plants, vol. 3, International Book Distributors, Dehradun, India, 2nd edition, 1999.

[2] R. S. Khare, S. Banerjee, and K. Kundu, "Coleus aromaticus benth-a nutritive medicinal plant of potential therapeutic value," International Journal of Pharma and Bio Sciences, vol. 2, no. 3, pp. B488-B500, 2011.

[3] A. Kumaran and R. J. Karunakaran, "Antioxidant and free radical scavenging activity of an aqueous extract of Coleus aromaticus," Food Chemistry, vol. 97, no. 1, pp. 109-114, 2006.

[4] A. P. A. D. Gurgel, J. G. da Silva, A. R. S. Grangeiro et al., "Antibacterial effects of Plectranthus amboinicus (Lour.) spreng (Lamiaceae) in methicillin resistant Staphylococcus aureus (MRSA)," Latin American Journal of Pharmacy, vol. 28, no. 3, pp. 460-464, 2009.

[5] P. Bhatt and P. S. Negi, "Antioxidant and antibacterial activities of Indian borage (Plectranthus amboinicus) leaf extracts," Food and Nutrition Sciences, vol. 3, no. 3, pp. 146-152, 2012.

[6] S. Annapurani and R. Priya, "Antimutagenic, antitumorogenic, and antigenotoxic effects of polyphenol extracts of selected medicinal plants," Indian Journal of Nutrition and Dietetics, vol. 36, no. 10, pp. 431-435, 1999.

[7] V. L. Singleton and J. A. Rossi, "Colorimetry of total phenolics with phosphomolybdic-phosphotungstic acid reagents," The American Journal of Enology and Viticulture, vol. 16, no. 3, pp. 144-158, 1965. 
[8] M. M. M. El Far and H. A. A. Taie, "Antioxidant activities, total anthocyanins, phenolics and flavonoids contents of some sweetpotato genotypes under stress of different concentrations of sucrose and sorbitol," Australian Journal of Basic and Applied Sciences, vol. 3, no. 4, pp. 3609-3616, 2009.

[9] J. S. Sun, Y. W. Tsuang, I. J. Chen, W. C. Huang, Y. S. Hang, and F. J. Lu, "An ultra-weak chemiluminescence study on oxidative stress in rabbits following acute thermal injury," Burns, vol. 24, no. 3, pp. 225-231, 1998.

[10] M. S. Blois, "Antioxidant determinations by the use of a stable free radical," Nature, vol. 181, no. 4617, pp. 1199-1200, 1958.

[11] M. Oyaizu, "Studies on product of browning reaction prepared from glucose amine," Japanese Journal of Nutrition, vol. 44, no. 6, pp. 307-315, 1986.

[12] J. Robak and R. J. Gryglewski, "Flavonoids are scavengers of superoxide anions," Biochemical Pharmacology, vol. 37, no. 5, pp. 837-841, 1988.

[13] P. Prieto, M. Pineda, and M. Aguilar, "Spectrophotometric quantitation of antioxidant capacity through the formation of a phosphomolybdenum complex: specific application to the determination of vitamin E," Analytical Biochemistry, vol. 269, no. 2, pp. 337-341, 1999.

[14] CLSI, Methods for Dilution Antimicrobial Susceptibility Tests for Bacteria That Grow Aerobically. Approved Standard, vol. 29, Clinical and Laboratory Standards Institute, 8th edition, 2009, CLSI document M07-A8.

[15] O. Yesil-Celiktas, C. Sevimli, E. Bedir, and F. Vardar-Sukan, "Inhibitory effects of rosemary extracts, carnosic acid and rosmarinic acid on the growth of various human cancer cell lines," Plant Foods for Human Nutrition, vol. 65, no. 2, pp. 158$163,2010$.

[16] R. Kahl and H. Kappus, "Toxicology of the synthetic antioxidants BHA and BHT in comparison with the natural antioxidant vitamin E," Zeitschrift für Lebensmittel-Untersuchung und Forschung, vol. 196, no. 4, pp. 329-338, 1993.

[17] V. R. Patel, P. R. Patel, and S. S. Kajal, "Antioxidant activity of some selected medicinal plants in Western region of India," Advances in Biological Research, vol. 4, no. 1, pp. 23-26, 2010.

[18] M. A. Howlader, F. Rizwan, S. Sultana et al., "Antimicrobal, antioxidant, and cytotoxic effects of methanolic extract of leaves and stems of Glycosmis pentaphylla," Journal of Applied Pharmaceutical Science, vol. 1, no. 8, pp. 137-140, 2011.

[19] P. D. Duh, "Antioxidant activity of burdock (Arctium lappa linné): its scavenging effect on free-radical and active oxygen," Journal of the American Oil Chemists' Society, vol. 75, no. 4, pp. 455-461, 1998.

[20] P. D. Duh, P. C. Du, and G. C. Yen, "Action of methanolic extract of mung bean hulls as inhibitors of lipid peroxidation and nonlipid oxidative damage," Food and Chemical Toxicology, vol. 37, no. 11, pp. 1055-1061, 1999.

[21] G. C. Yen and H. Y. Chen, "Antioxidant activity of various tea extracts in relation to their antimutagenicity," Journal of Agricultural and Food Chemistry, vol. 43, no. 1, pp. 27-32, 1995.

[22] V. C. Lobo, A. Phatak, and N. Chandra, "Antioxidant and free radical scavenging activity of Hygrophila schulli (Buch.Ham.) Almeida and Almeida seeds," Advances in Bioresearch, vol. 1, no. 2, pp. 72-78, 2010.

[23] A. Kumaran and R. J. Karunakaran, "In vitro antioxidant activities of methanol extracts of five Phyllanthus species from India," LWT-Food Science and Technology, vol. 40, no. 2, pp. 344-352, 2007.
[24] S. Pierre, L. Crosbie, and A. K. Duttaroy, "Inhibitory effect of aqueous extracts of some herbs on human platelet aggregation in vitro," Platelets, vol. 16, no. 8, pp. 469-473, 2005.

[25] B. Østerud, "A global view on the role of monocytes and platelets in atherogenesis," Thrombosis Research, vol. 85, no. 1, pp. 1-22, 1997.

[26] P. S. Negi, "Plant extracts for the control of bacterial growth: efficacy, stability and safety issues for food application," International Journal of Food Microbiology, vol. 156, no. 1, pp. 7-17, 2012.

[27] A. P. A. D. Gurgel, J. G. da Silva, A. R. S. Grangeiro et al., "In vivo study of the anti-inflammatory and antitumor activities of leaves from Plectranthus amboinicus (Lour.) Spreng (Lamiaceae)," Journal of Ethnopharmacology, vol. 125, no. 2, pp. 361-363, 2009.

[28] A. Kumaran and R. J. Karunakaran, "Activity-guided isolation and identification of free radical-scavenging components from an aqueous extract of Coleus aromaticus," Food Chemistry, vol. 100, no. 1, pp. 356-361, 2007.

[29] T. Makino, T. Ono, E. Muso, H. Yoshida, G. Honda, and S. Sasayama, "Inhibitory effects of rosmarinic acid on the proliferation of cultured murine mesangial cells," Nephrology Dialysis Transplantation, vol. 15, no. 8, pp. 1140-1145, 2000.

[30] F. A. Tomas-Barberan and M. N. Clifford, "Dietary hydroxybenzoic acid derivatives nature, occurrence and dietary burden," Journal of the Science of Food and Agriculture, vol. 80, no. 7, pp. 1024-1032, 2000.

[31] U. J. Joshi, A. S. Gadge, P. D’Mello, R. Sinha, S. Srivastava, and G. Govil, "Anti-inflammatory, antioxidant and anticancer activity of quercetin and its analogues," International Journal of Pharmaceutical and Biomedical Research, vol. 2, no. 4, pp. 17561766, 2011.

[32] P. Rattanachaikunsopon and P. Phumkhachorn, "Contents and antibacterial activity of flavonoids extracted from leaves of Psidium guajava," Journal of Medicinal Plant Research, vol. 4, no. 5, pp. 393-396, 2010.

[33] J. R. Sheu, G. Hsiao, P. H. Chou, M. Y. Shen, and D. S. Chou, "Mechanisms involved in the antiplatelet activity of rutin, a glycoside of the flavonol quercetin, in human platelets," Journal of Agricultural and Food Chemistry, vol. 52, no. 14, pp. 44144418, 2004. 

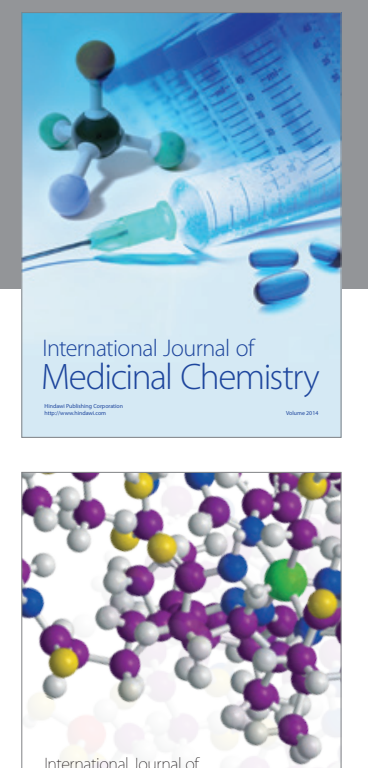

\section{Carbohydrate} Chemistry

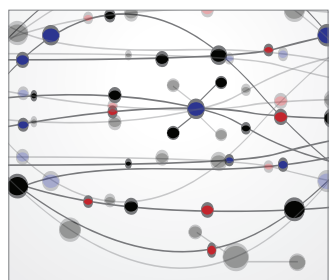

The Scientific World Journal
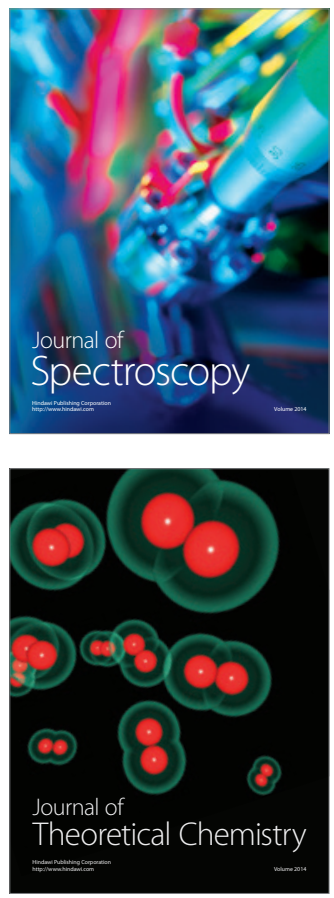
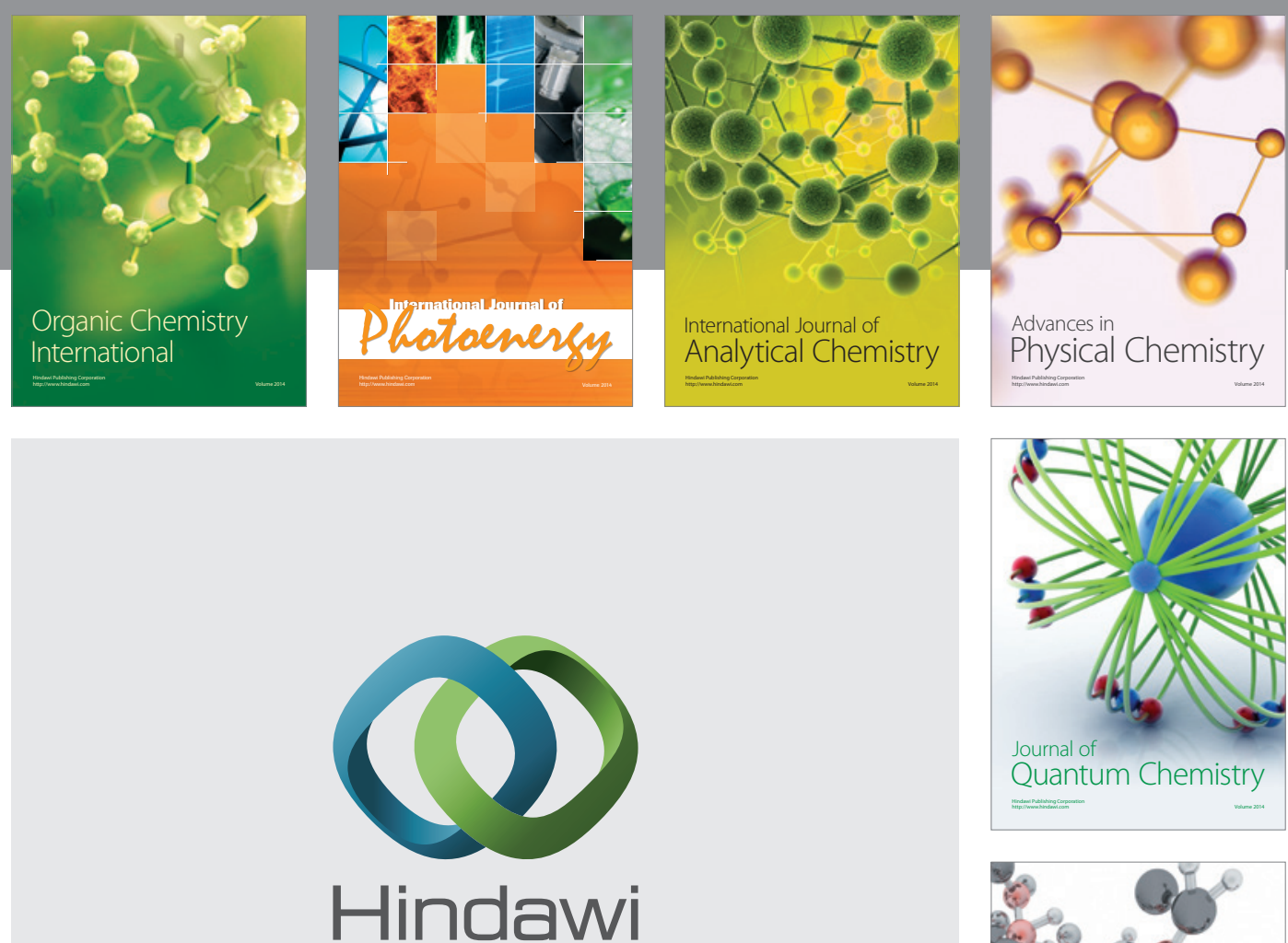

Submit your manuscripts at

http://www.hindawi.com

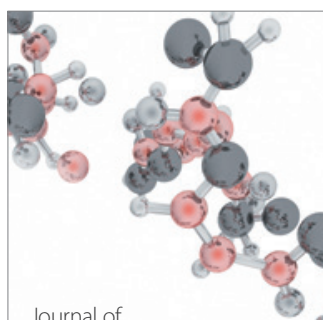

Analytical Methods

in Chemistry

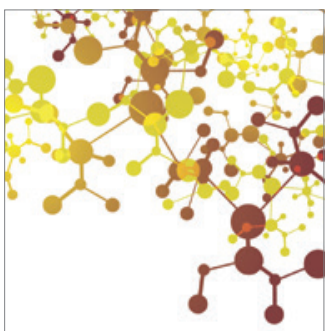

Journal of

Applied Chemistry

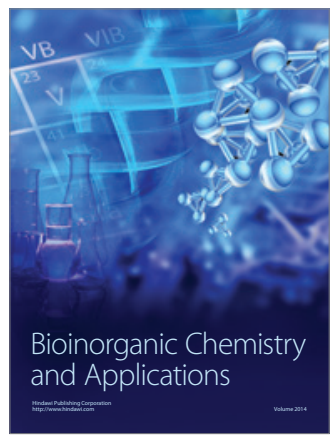

Inorganic Chemistry
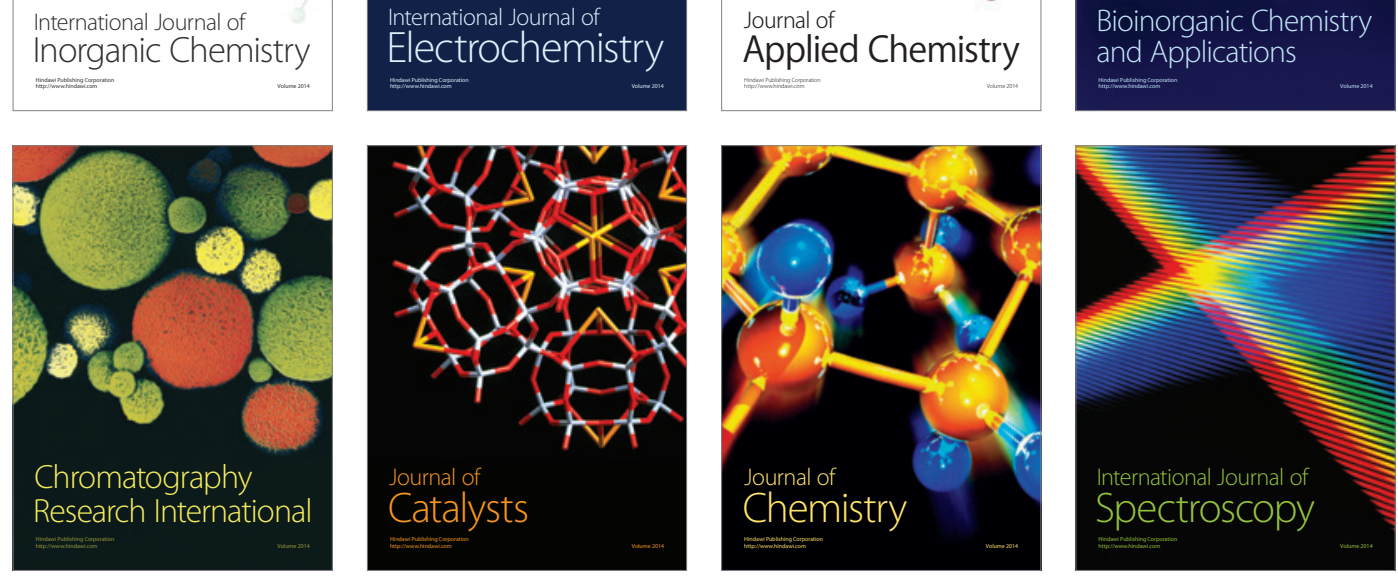